\title{
Penentuan Jalur Terpendek Menggunakan Google Maps API pada Sistem Informasi Geografis (GIS) Panti Sosial di Kota Tasikmalaya
}

\author{
Hariska Paunsyah ${ }^{1}$, Husni Mubarok ${ }^{2}$, Rahmi Nur Shofa ${ }^{3}$ \\ ${ }^{1,2,3}$ Porogram Studi Informatika Universitas Siliwangi \\ hariska.paunsyah20@gmail.com ${ }^{1}$,husni@unsil.ac.id ${ }^{2}$, rahmi.shofa@unsil.ac.id ${ }^{3}$
}

\section{INFORMASI ARTIKEL}

Sejarah Artikel:

Diterima Redaksi:

Revisi Akhir:

Diterbitkan Online:

\begin{tabular}{l} 
KATA KUNCI \\
\hline Algoritma Dijkstra \\
Extreme Programming \\
Panti Sosial \\
Jalur Terpendek \\
Sistem Informasi Geografis \\
KORESPONDENSI \\
\hline
\end{tabular}

Telepon: +62 85353634554

E-mail: rahmi.shofa@unsil.ac.id

\begin{abstract}
A B S T R A K
Kurangnya informasi mengenai lokasi Panti sosial yang ada, menyebabkan donator mengalami kesulitan untuk menyalurkan dana bantuannya. Pembangunan Sistem Informasi Geografis (SIG) pada penelitian ini dimaksudkan untuk memudahkan donator dalam mengetahui serta mendapatkan informasi yang akurat mengenai keberadaan Panti Sosial yang ada di Kota Tasikmalaya. Penerapan Algoritma Dijkstra dimaksudkan untuk menghitung jalur terpendek dari tempat donatur ke Panti Sosial yang akan dituju, sehingga memudahkan donatur dalam menyalurkan dana bantuannya. Pembangunan SIG Panti Sosial menggunakan pendekatan Object Oriented Programming dengan metode Extreme Programing, hal tersebut dikarenakan SIG yang dibangun berdasarkan kebutuhan dari Donatur. SIG Panti Sosial dapat memberikan kemudahan bagi Donatur dalam mencari lokasi Panti Sosial yang ada di Kota Tasikmalaya, serta memberikan informasi jalur terpendek dari lokasi donator ke lokasi Panti Sosial yang akan dituju.
\end{abstract}

\section{PENDAHULUAN}

Menurut kamus besar bahasa Indonesia tahun 2013, Panti adalah Rumah, atau kediaman sedangkan panti asuhan merupakan rumah tempat memelihara dan merawat anak yatim dan yatim piatu, dan sebagainya. Sehingga tempat ini sagatlah tepat untuk menyalurkan bantuan. Hal ini sesuai dengan firman Allah SWT, dalam QS Al-ma'un, ayat 1-3 yang artinya sebagai berikut: "(1) Tahukah kamu (orang) yang mendustan agama? (2) Itulah orang yang menghardik anak yatim, (3) dan tidak dianjurkan memberi makan orang miskin".

Panti merupakan salah satu lembaga perlindungan anak yang berfungsi memberikan perlindungan baik kepada anak-anak maupun orang yang sudah lanjut usia. Pada umumnya panti mengatasi berbagai permasalahan sosial yang terjadi pada anak. Di Kota Tasikmalaya misalnya, memiliki 26 lembaga panti yang terdaftar pada Dinas Sosial Kota Tasikmalaya. Panti tersebut terbagi menjadi 5 jenis, yaitu panti anak terlantar, panti penyandang disabilitas, panti tuna sosial, panti lanjut usia, dan panti rehabilitas. Namun banyaknya panti tersebut tidak diikuti dengan sistem informasi yang memadai.
Masyarakat umum khususnya donatur yang ingin mendonasikan hartanya sangat kesulitan untuk mencari tempat dan informasi mengenai panti yang ada di Kota Tasikmalaya, seringkali kebanyakan dari donatur memberikan donasinya kepada gelandangan atau pengemis di jalan raya. Selain itu, untuk mengetahui alamat dan informasi panti seringkali bertanya kepada masyarakat sekitar dan akan memakan waktu yang lama serta cara ini kurang efektif, Banyak pula donatur mencari informasi dengan menelpon Dinas Sosial untuk mencari panti sosial di Kota Tasikmalaya yang rentan adanya kesalahan penangkapan berita yang didapatkan.

Sistem informasi geografis (SIG) merupakan cara untuk memberikan informasi data panti, Karena sistem informasi geografis berbasis web ini dapat membantu untuk mengambil keputusan dalam berbagi informasi panti. SIG mudah dan cepat dalam pengeloalaan informasi, sebab SIG sangat memungkinkan untuk memiliki informasi up-to-date, yang direkomendasi dan diorientasi kepada donatur demi menjamin keamanan mereka dalam proses mendonasikan dan mencari tempat panti sosial. Salah satu metode yang digunakan sebagai solusi pencarian rute terpendek adalah algoritma Dijkstra, yaitu dengan mencari lintasan terpendek dari suatu simpul ke 
semua pasangan simpul menggunakan prinsip greedy dengan memilih bobot minimum

\section{LANDASAN TEORI}

\subsection{Panti Sosial}

Menurut Departemen Sosial RI (2008: 11) Panti sosial merupakan suatu lembaga penyelenggara pelayanan kesejahteraan sosial yang memiliki tugas dan fungsi melakukan pendampingan terhadap keluarga dan masyarakat dalam pengasuhan anak.

Tujuan Panti Sosial untuk mewujudkan keanekaragaman pelayanan sosial dan meningkatkan pengetahuan serta keterampilan bagi remaja yang mengalami masalah sosial sehingga dapat memiliki kemampuan dan keterampilan.

\subsection{Sistem Informasi Geografis ( SIG )}

Sistem Informasi Georafis atau Georaphic Information Sistem (GIS) merupakan suatu sistem yang mengcapture, mengecek, mengintegrasikan, memanipulasi, menganalisa, dan menampilkan data yang secara spasial mereferensikan kepada kondisi bumi.

SIG pertama kali diperkenalkan di Indonesia pada tahun 1972 dengan nama Data Banks for Develompment (Rais, 2005). Istilah Sistem Informasi Geografis muncul setelah dicetuskan oleh General Assembly dari International Geographical Union di Ottawa Kanada pada tahun 1967. SIG kemudian dikembangkan oleh Roger Tomlinson dan dikenal dengan nama CGIS (Canadian GIS-SIG Kanada) yang digunakan untuk menyimpan, menganalisa dan mengolah data yang dikumpulkan untuk inventarisasi Tanah Kanada (CLI-Canadian Land Inventory). SIG memiliki fungsi -fungsi dasar sebagai berikut :

1. Akuisisi data dan proses awal meliputi: digitasi, editing, pembangunan topologi, konversi format data, pemberian atribut dan lain-lain.

2. Pengelolaan database meliputi : pengarsipan data, permodelan bertingkat, pemodelan jaringan pencarian atribut dan lain-lain.

3. Pengukuran keruangan dan analisis meliputi : operasi pengukuran, analisis daerah penyanggga, overlay, dan lain-lain.

4. Penayangan grafis dan visualisasai meliputi : transformasi skala, generalisasi, peta topografi, peta statistic, tampilan perspektif.

\subsection{Algoritma Dijkstra}

Algoritme Dijkstra, diambil dari nama seorang ilmuwan komputer yang menemukannya, yaitu Edsger Dijkstra. Algoritma Dijkstra merupakan greedy algorithm yang dipakai dalam memecahkan permasalahan jarak terpendek untuk sebuah graf berarah dengan bobot-bobot sisi yang bernilai tak negatif. Algortima Dijkstra dipublikasi tahun 1959 pada jurnal Numerische Mathematik yang berjudul "A Note on Two Problems in

2 Hariska Paunsyah
Connexion with Graphs“. (Brassard and Bratley [1988, pp. 87-92]).

Algoritma Dijkstra menggunakan graph berarah untuk penentuan rute listasan terpendek, dikarenakan Djikstra merupakan algoritma dalam pemecahan persoalan optimasi pencarian lintasan terpendek pada sebuah lintasan yang mempunyai panjang minimum dari verteks a ke $\mathbf{z}$ dalam graph berbobot, bobot tersebut adalah bilangan positif jadi tidak dapat dilalui oleh node negatif. Namun jika terjadi demikian, maka penyelesaian yang diberikan adalah infiniti (Tak Hingga).

\subsection{Google Maps API}

Fitur Google Maps API dapat ditambahkan dalam web yang dibangun. Pemanfaatan Google Maps API dapat menghemat waktu dan biaya untuk membangun aplikasi peta digital yang handal, sehingga pembangunan aplikasi lebih fokus pada data-data yang diolah.

\subsection{Penelitian Teerkait}

Berikut beberapa penelitian yang terkait dengan penelitian yang dilakukan:

a. Penelitian oleh Wibowo (2015) dengan judul Sistem Informasi Geografis Menentukan Lokasi Pertambangan Batu Bara di Provinsi Bengkulu berbasis Web. Aplikasi ini membahas tentang penentuan lokasi petambangan yang ada di provinsi Bengkulu melalui pendekan terstruktur, metode yang digunakan dalam penelitian ini adalah pendekatan perancangan terstruktur sihingga dapat dengan mudah menentukan lokasi batu bara pada aplikasi yang dibuat.

b. Penelitian oleh Yulia (2015) dengan judul Pencarian SPBU terdekat dan penentuan jarak terpendek menggunakan algoritma Dijkstra. Penelitian ini menhasilkan tentang pemetaan lokasi, pencarian lokasi, dan penentuan jalur terpendek untuk mencapai lokasi SPBU. Pencarian SPBU terdekat dipengaruhi oleh kriteria, cost, dan reverse_cost. Dimana untuk jalan satu arah diberikan nilai revers_cost sebesar 1.000.000, sehingga jalan ini tidak akan pernah dipilih. Penerapan algoritma dijkstra merekomendasikan jalur terpendek jarak tempuh guna memberikan efisiensi penggunaan bahan bakar kendaraan bermotor.

\section{METODOLOGI}

Pada penelitian ini terdapat dua tahapan, yaitu pengumpulan data dan pengembangan aplikasi, dengan langkah sebagai berikut:

\subsection{Pengumpulan Data}

Pada tahap ini dilakukan pengumpulan data melalui wawancara, observasi, dan studi literatur terhadap beberapa penelitian yang terkait dengan penelitian yang akan dilakukan 


\subsection{Pengembangan Sistem}

Pengembangan system dilakukan menggunakan metode eXtreme Programing. Extreme Programming(Pressman, 2010) dengan tahapan seperti tertera pada gambar 1 .

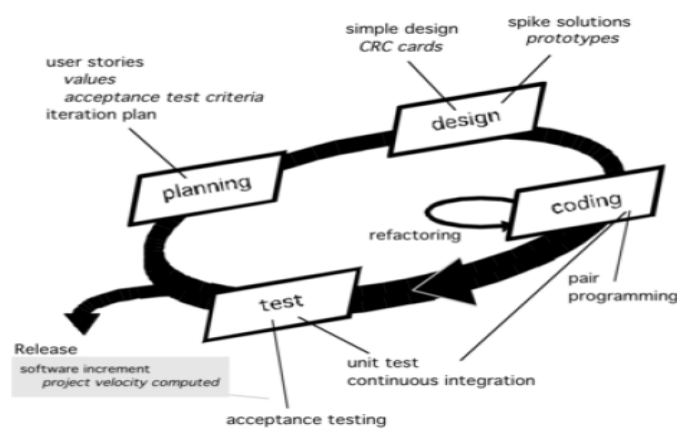

Gambar 1. Extreame Programming (Pressman, 2010)

\section{c. Planning (Perencanaan)}

Tihap ini dimulai dari pengumpulan kebutuhan untuk memahami konteks bisnis. Tahap ini juga mendefinisikan output yang akan dihasilkan serta fitur yang dimiliki oleh SIG yang akan dibangun.

d. Design (Perancangan)

Pada tahap ini dilakukan analisis terhadap prosedur yang sedang berjalan dan perancangan sistem.

e. Coding (Pengkodean)

Pada tahap ini melakukan implementasi dari hasil perancangan ke bahasa pemrograman PHP dengan bantuan Framework Laravel 5.3.

f. Test (Pengujian)

Pada tahap ini dilakukan pengujian terhadap sistem yang dibangun menggunakan metode blackbox testing.

\section{HASIL DAN PEMBAHASAN}

\subsection{Prosedur usulan SIG Panti Sosial}

Sistem yang diusulkan diharapkan memberi kemudahan untuk donator dalam menyalurkan bantuan kepada panti social, maka prosedur system usulan adalah seperti tertera pada Gambar 2.

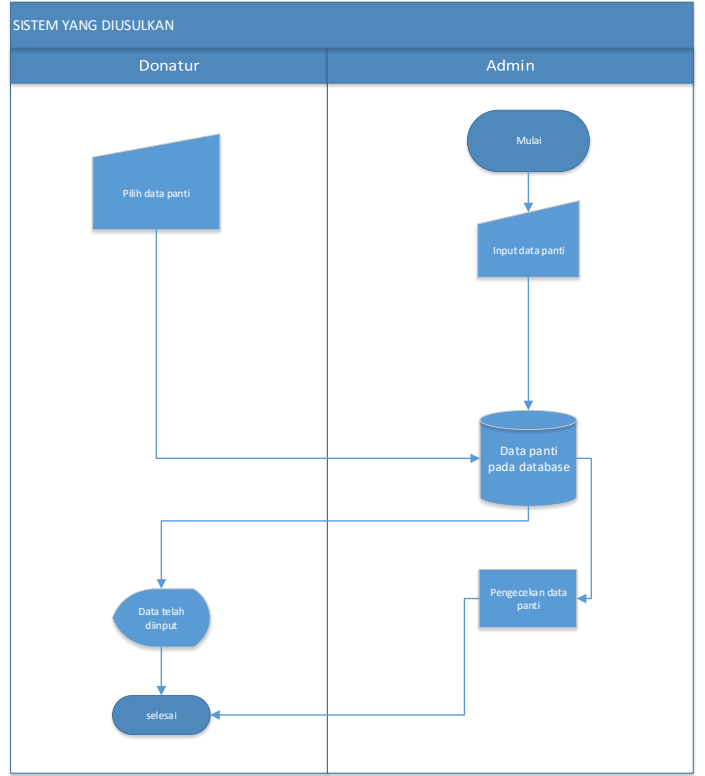

Gambar 2. Prosedur yang diusulkan

\subsection{Perancangan SIG PAnti Sosial}

Sistem yang akan dibangun dapat diakses oleh dua aktor seperti tertera pada Tabel 1 .

Tabel 1. Identifikasi aktor

\begin{tabular}{cl}
\hline Nama Aktor & \multicolumn{2}{c}{ Keterangan } \\
\hline \multirow{3}{*}{ Admin } & Hak akses berupa pengelolaan \\
& semua fitur pada aplikasi. \\
& $\begin{array}{l}\text { Dimana dapat mengubah, } \\
\text { menghapus, menampilkan data }\end{array}$ \\
& yang ada di aplikaksi. \\
\hline \multirow{3}{*}{ Donatur } & Pengguna merupakan hak akses \\
& untuk melihat peta pada aplikasi, \\
& namun tidak dapat melakukan \\
& proses mengubah aplikasi.
\end{tabular}

Use case diagram untuk system yang dibangun seperti tertera pada Gambar 3.

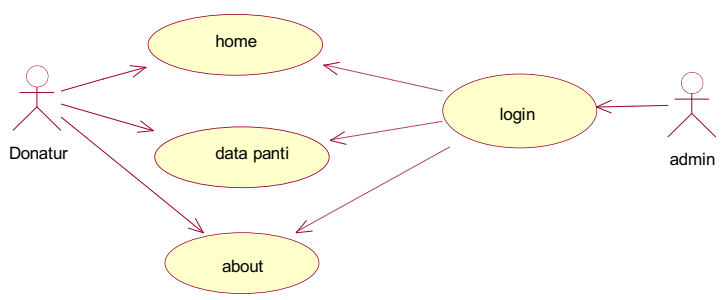

Gambar 3. Use case diagram SIG Panti Sosial

Admin dapat melakukan update data Panti Sosial yang bisa dikunjungi, dan Donatur dapat melihat data Panti Sosial yang bisa dikunjungi serta mengetahui rute ke Panti Sosial tujuan.

Sequence diagram dimaksudkan untuk menggambarkan interaksi antar actor dengan sistem seperti yang tertera pada Gambar 4. 


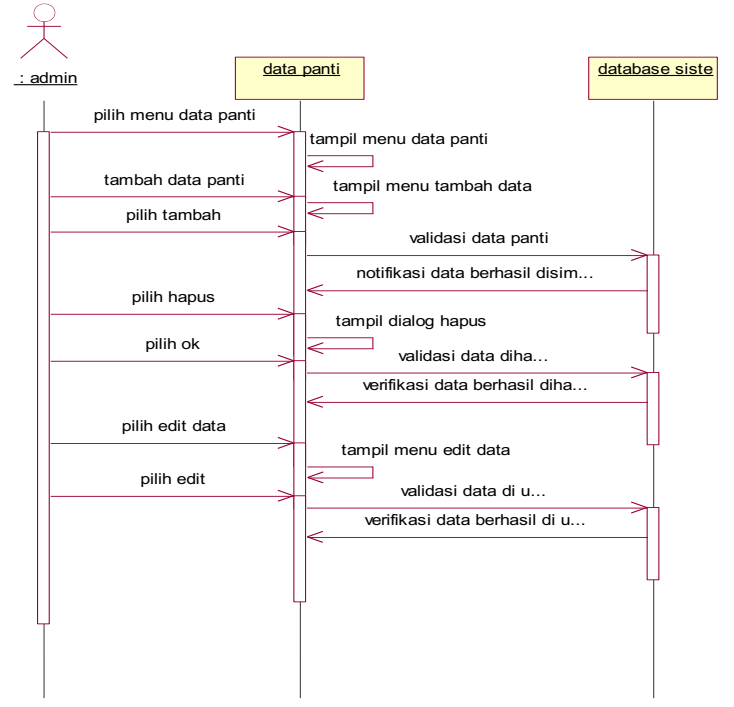

Gambar 4. Sequence diagram SIG Panti Sosial

Data yang diolah pada SIG Panti Sosial terdapat pada Gambar 5.

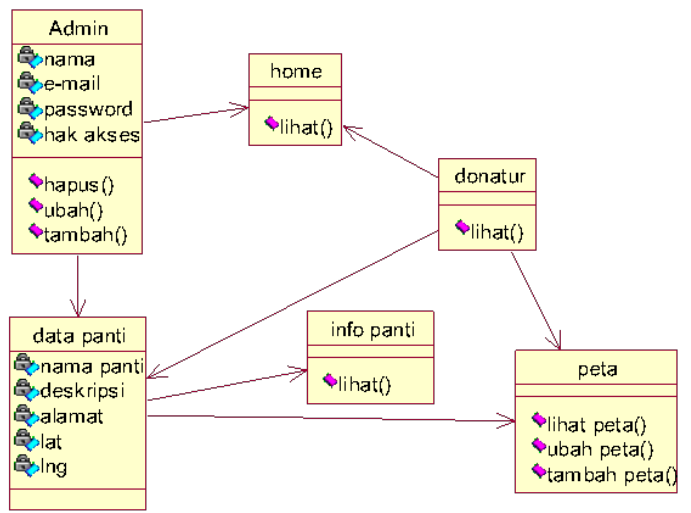

Gambar 5. Class diagram SIG Panti Sosial

Peran, fungsi, dan perilaku objek dalam SIG Panti sosial dapat digambarkan dalam Collaboration diagram seperti yan tertera pada Gambar 6 .

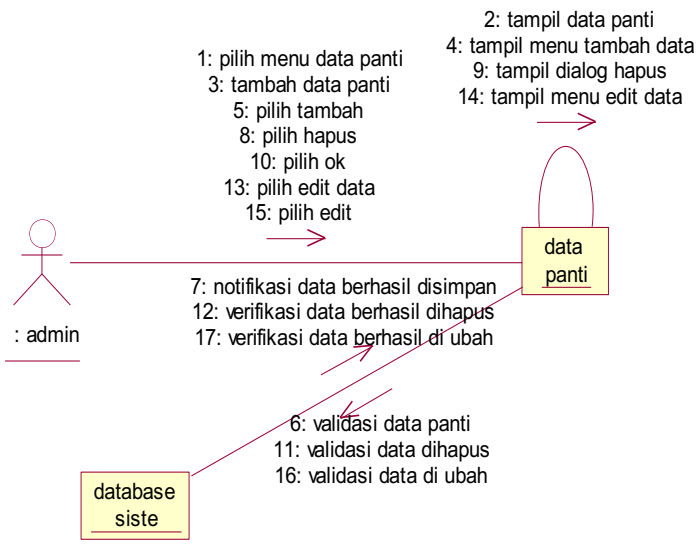

Gambar 6. Collaboration diagram SIG Panti Sosial

State diagram untuk sisi Admin pada SIG Panti Sosial tertera pada Gambar 7.

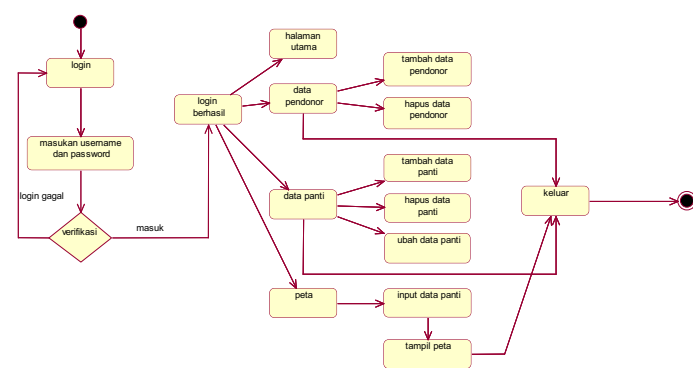

Gambar 7. State diagram SIG Panti Sosial

\subsection{Implementasi SIG Panti Sosial}

Pada tampilan awal SIG Panti Sosial untuk sisi donatur terdapat menu home seperti yang tertera pada Gambar 8.

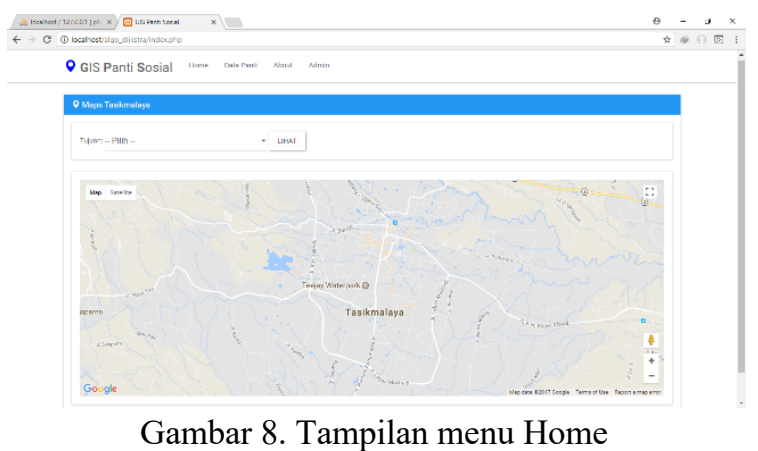

Kemudian terdapat pilihan data panti untuk memilih panti mana yang akan dituju, setelah dipilih donatur langsung menentukan lokasi yang diingikan untuk memulai proses pencarian rute terdekat menuju Panti Sosial yang diinginkan

\subsection{Pengujian SIG Panti Sosial}

Sebuah program yang diterapkan harus bebas dari kesalahan-kesalahan atau error. Oleh karena itu, dilakukan pengujian terlebih dahulu untuk menemukan kesalahankesalahan yang mungkin terjadi, pada tahap ini metode pengujian yang digunakan adalah metode pengujian black box.

Pengujian black box berfokus pada persyaratan fungsional perangkat lunak dengan tujuan menemukan kesalahan antara lain:

1. Fungsi-fungsi yang tidak benar atau fungsi yang hilang

2. Kesalahan pada interface

3. Kesalahan dalam struktur data

4. Kesalahan kinerja system

Rencana pengujian pada penelitian ini tertera pada tabel 2 .

Tabel 2. Rencana Pengujian SIG Panti Sosial

\begin{tabular}{ccc}
$\begin{array}{c}\text { Menu Yang } \\
\text { Diuji }\end{array}$ & Detail Pengujian & Jenis Uji \\
\hline Masuk & $\begin{array}{c}\text { Masuk sesuai } \\
\text { dengan hak akses }\end{array}$ & Black box \\
\hline
\end{tabular}




\begin{tabular}{ccc}
\hline Data Panti & Melihat data panti & Black box \\
\hline Menu Home & $\begin{array}{c}\text { Mengelola menu } \\
\text { home }\end{array}$ & Black box \\
\hline logout & $\begin{array}{c}\text { Keluar dari } \\
\text { Aplikasi }\end{array}$ & Black box \\
\hline
\end{tabular}

Pengujian yang dilakukan pada SIG Panti Sosial tertera pada Tabel 3.

Tabel 3. Pengujian SIG Panti Sosial

\begin{tabular}{|c|c|c|c|c|c|}
\hline No & $\begin{array}{c}\text { Taha } \\
\text { pan }\end{array}$ & $\begin{array}{c}\text { Hasil } \\
\text { yang } \\
\text { diharap } \\
\text { kan }\end{array}$ & $\begin{array}{c}\text { Uji } \\
\text { Kasus }\end{array}$ & $\begin{array}{c}\text { Hasil } \\
\text { Uji } \\
\text { Kasus }\end{array}$ & $\begin{array}{c}\text { Respo } \\
\text { n } \\
\text { Aplik } \\
\text { asi }\end{array}$ \\
\hline \multirow[t]{3}{*}{1} & \multirow[t]{3}{*}{ Login } & \multirow[t]{3}{*}{$\begin{array}{l}\text { Admin } \\
\text { bisa } \\
\text { masuk ke } \\
\text { aplikasi }\end{array}$} & $\begin{array}{l}\text { Userna } \\
\text { me dan } \\
\text { passwor } \\
\text { d } \\
\text { dikoson } \\
\text { gkan }\end{array}$ & $\begin{array}{l}\text { aplikasi } \\
\text { menam } \\
\text { pilkan } \\
\text { informa } \\
\text { si } \\
\text { kesalah } \\
\text { an }\end{array}$ & $\begin{array}{l}\text { Diteri } \\
\text { ma }\end{array}$ \\
\hline & & & $\begin{array}{l}\text { Userna } \\
\text { me dan } \\
\text { passwor } \\
\text { d } \\
\text { diisikan } \\
\text { dengan } \\
\text { isian } \\
\text { yang } \\
\text { salah }\end{array}$ & $\begin{array}{l}\text { Aplikas } \\
\text { i } \\
\text { menam } \\
\text { pilkan } \\
\text { informa } \\
\text { si } \\
\text { kesalah } \\
\text { an }\end{array}$ & $\begin{array}{l}\text { Diteri } \\
\text { ma }\end{array}$ \\
\hline & & & $\begin{array}{l}\text { Userna } \\
\text { me dan } \\
\text { passwor } \\
d \text { benar }\end{array}$ & $\begin{array}{l}\text { Aplikas } \\
\mathrm{i} \\
\text { menam } \\
\text { pilkan } \\
\text { menu } \\
\text { utama }\end{array}$ & $\begin{array}{l}\text { Diteri } \\
\text { ma }\end{array}$ \\
\hline \multirow[t]{3}{*}{2} & \multirow[t]{3}{*}{$\begin{array}{l}\text { Menu } \\
\text { Data } \\
\text { Panti }\end{array}$} & \multirow{3}{*}{$\begin{array}{l}\text { Admin } \\
\text { dapat } \\
\text { menamb } \\
\text { ahkan, } \\
\text { menguba } \\
\text { h dan } \\
\text { menghap } \\
\text { us data } \\
\text { Panti }\end{array}$} & $\begin{array}{l}\text { Tambah } \\
\text { data } \\
\text { panti } \\
\text { baru }\end{array}$ & $\begin{array}{l}\text { Aplikas } \\
\text { i } \\
\text { menyi } \\
\text { mpan } \\
\text { data } \\
\text { panti }\end{array}$ & $\begin{array}{l}\text { Diteri } \\
\text { ma }\end{array}$ \\
\hline & & & $\begin{array}{l}\text { Ubah } \\
\text { data } \\
\text { panti }\end{array}$ & $\begin{array}{l}\text { Aplikas } \\
\mathrm{i} \\
\text { menyi } \\
\text { mpan } \\
\text { hasil } \\
\text { peruba } \\
\text { han } \\
\text { data } \\
\text { panti } \\
\end{array}$ & $\begin{array}{l}\text { Diteri } \\
\text { ma }\end{array}$ \\
\hline & & & $\begin{array}{l}\text { Hapus } \\
\text { data } \\
\text { panti }\end{array}$ & $\begin{array}{l}\text { Aplikas } \\
\text { i } \\
\text { menam } \\
\text { pilkan } \\
\text { konfir } \\
\text { masi } \\
\text { sebelu }\end{array}$ & $\begin{array}{l}\text { Diteri } \\
\text { ma }\end{array}$ \\
\hline
\end{tabular}

\begin{tabular}{|c|c|c|c|c|c|}
\hline & & & & $\begin{array}{l}\text { m } \\
\text { mengha } \\
\text { pus }\end{array}$ & \\
\hline 3 & $\begin{array}{l}\text { Menu } \\
\text { home }\end{array}$ & $\begin{array}{l}\text { Admin } \\
\text { dapat } \\
\text { menamb } \\
\text { ahkan, } \\
\text { mengola } \\
\text { h data } \\
\text { untuk } \\
\text { pemetaa } \\
\text { n }\end{array}$ & $\begin{array}{l}\text { Pilih } \\
\text { panti } \\
\text { tujuan }\end{array}$ & $\begin{array}{l}\text { Aplikas } \\
\text { i } \\
\text { menyi } \\
\text { mpan } \\
\text { menam } \\
\text { pilkan } \\
\text { pemeta } \\
\text { an panti } \\
\text { dan } \\
\text { jalur }\end{array}$ & $\begin{array}{l}\text { Diteri } \\
\text { ma }\end{array}$ \\
\hline
\end{tabular}

5. Kelebiahan dan Kekurangan

a. Kelebihan

Kelebihan Sistem Informasi Geografis ( GIS ) Panti Sosil di Kota Tasikmalaya dengan Penentuan Jalur Terpendek menggunakan Algoritma Dijksta yang dibangun adalah sebagai berikut :

1. Sistem Informasi Geografis ini dikembangkan dengan mengunakan google maps dan algoritma jalur terpendek.

2. Aplikasi dapat dengan mudah melihat data panti sehingga tidak mengurangi ruang penyimpanan berkas dan mengefisienkan waktu untuk mecari panti.

\section{b. Kekurangan}

Adapun kekurangan dari Sistem Informasi Geografis ( GIS ) Panti Sosil di Kota Tasikmalaya dengan Penentuan Jalur Terpendek menggunakan Algoritma Dijksta yang sudah dibangun yaitu :

1. Sistem ini tidak dilemkapi dengan waktu yang ditepuh

2. Sistem ini belum dirancang untuk berbasi mobile

3. Sistem ini belum otomatis memilih tempat donatur ke tujuan

4. Sistem ini menggunakan jalur angkutan kota yang beroperasi

\section{KESIMPULAN}

Setelah melakukan serangkaian penelitian, maka kesimpulan yang diperoleh adalah sebagai berikut :

1. Telah dihasilkan merancang dan mebangun sistem Penentuan Jarak Tependek menggunakan Algoritma Dijkstra pada Sistem Informasi Geografis ( GIS ) Panti Sosial di Kota Tasikmalaya.

2. Telah dihasilkan pemanfaatan fitur google maps yang fungsinya supaya admin bisa menentukan jarak terpendek yang akan dilalui oleh donatur dalam pencarian panti sosial dan dapat mengefisienkan waktu pencarian Panti Sosial

Berdasarkan kesimpulan yang telah dikemukakan, didapatkan beberapa saran untuk pengembangan lebih lanjut, diantaranya : 
1. Akan lebih optimal jika sistem ini dapat memberikan fitur pemberitahuan status waktu yang ditempuh dan pemilihan bangan jalur yang akan dipilih.

2. Akan lebih baik jika Sistem ini dilengkapi dengan waktu jarak ditepuh dan alternatif tujuan.

3. Akan lebih baik jika Sistem ini dirancang untuk berbasis mobile

\section{DAFTAR PUSTAKA}

[1] Antonio, Soleh dkk. (2013). Sistem Informasi Geografis Pariwisata Berbasis Web Dan Pencarian Jalur Terpendek Dengan Algoritma Dijkstra. Jurnal EECCIS, 125-130.

[2] Fitria, Apri. (2013). Implementasi Algoritma Dijkstra Dalam Aplikasi Untuk Menentukan Lintasan Terpendek Jalan Darat Antar Kota Di Sumatera Bagian Selatan. Jurnal Sistem Informasi, 611-621.

[3] Joko, Muhammad. (2016). Rancang Bangun Webgis Pemetaan Lokasi Panti Sosial Menggunakan Pmapper. Jurnal Rekayasa Dan Manajemen Sistem Informasi, 137-142.

[4] Lee, Jhon. (2003). The use of geographical information systems in climatology and meteorology. Progress in Physical Geography, 313-330.

[5] Mufti, Yusuf. (2015).Panduan Mudah Pengembangan Google Map Android. Yogyakarta: Andi.

[6] Pressman, Roger S. (2010). Rekayasa Perangkat Lunak. Alih Bahasa: Adi Nugraha, dkk. Yogyakarta: Andi.

[7] Septya, Awang dkk. (2016). Sistem Informasi Geografi (SIG) Pencarian ATM Bank Kaltim Terdekat dengan Geolocation dan Haversine Formula Berbasis Web. Jurnal Intofel, 1-8.

[8] Sri, Endah. (2014). Penentuan Rute Terpendek Pengambilan Sampah di Kota Merauke Menggunakan Algoritma Dijkstra. SEMANTIK, 1-7.

[9] Wibowo, dkk. (2015). Sistem Informasi Geografis Menentukan Lokasi Pertambangan Batu Bara di Provinsi Bengkulu berbasis Web. Jurnal Media Infotama no ISSN : 1858-2680

[10] Yulia dkk. (2015). Pencarian SPBU terdekat dan penentuan jarak terpendek menggunakan algoritma Dijkstra. Jurnal Nasional Teknik Elektro no ISSN : 2302-2949

\section{BIODATA PENULIS}

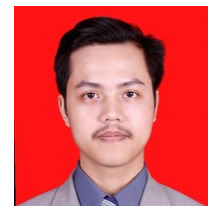

Hariska Paunsyah

Mahasiswa Informatika, Fakultas Teknik, Universitas Siliwangi

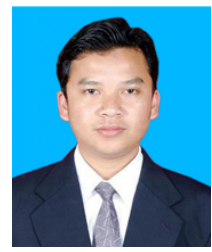

Husni Mubarok

Dosen Informatika, Fakultas Teknik, Universitas Siliwangi

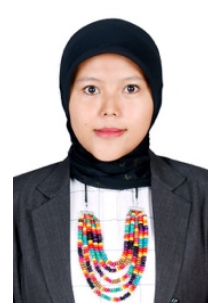

Rahmi Nur Shofa

Dosen Informatika, Fakultas Teknik, Universitas Siliwangi 